both can certainly bring about a reduction in the number of bacteria in the air, as can ultra-violet irradiation of the air in the upper part of the room.

Although there are good general reasons for thinking that a reduction in the microbial content of the air might reduce the incidence of infection, direct evidence of such an effect is extremely scanty. Indeed, it hardly extends beyond the observation of a reduction in streptococcal cross-infection in hospital wards following measures to prevent air-contamination from floors and bedding. At the same time the number of occasions on which the relation has been sought is not great, and adequate methods for the detection of pathogenic bacteria or viruses in the air have been developed only in the last few years. So far only a few large-scale tests of aerial disinfectants and the like have been made, but it must be said that none of those recorded in the literature has shown convincingly that the use of air disinfectants reduced the spread of infection. Air disinfectants should therefore still be regarded as in the experimental stages.

\section{Chemotherapy and Immunity}

Q.-To what extent does the use of sulphonamides and antibiotics prevent children from building up resistance to infection?

A.- - If an infection can be brought to an end by any form of chemotherapy before the body has had time to react to it fully, subsequent immunity will naturally be less than that following an uninterrupted attack. How deficient it will be depends on how early the treatment is given, and on the nature and rapidity of action of the drug used. Sulphonamides act slowly and do not actually kill bacteria ; this is left to the normal defences of the body; and consequently the danger of relapse owing to deficient specific resistance after sulphonamide treatment is small. On the other hand, penicillin kills bacteria, and if, for instance, it is given early in scarlet fever, the attack is aborted, and a relapse is liable to occur which may be as severe as the original illness. The remedy in this case is to continue penicillin treatment not only until symptoms and signs have disappeared but until the streptococcus has been eliminated from the throat, which will usually mean six to seven days. The same difficulty has been encountered in the treatment of typhoid fever with chloramphenicol, and here it is wise to anticipate a relapse by giving a second course. In most other infections there is no particular liability to relapse, unless dosage and duration of treatment are inadequate by ordinary standards. There are no good grounds for delaying treatment in any infection in order to allow the body to iplay its own part in overcoming it.

\section{Amidone}

Q.-Are there any dangers in prolonged treatment with .amidone (5 $\mathrm{mg}$. nightly)?

A.-Prolonged administration of amidone in therapeutic doses is unlikely to be followed by any dangerous organic -disorders. It should be remembered, however, that it is a drug of addiction, though in the very small dosage suggested the danger of addiction, even with prolonged treatment, is extremely slight.

\section{Venesection}

Q. -What are the modern indications for venesection? What is a reasonable amount of blood to remove at a single sitting?

A.- There are two chief indications for venesection: polycythaemia vera and heart failure. In polycythaemia vera repeated venesection is probably as good a way as any of controlling the situation. It is usual to remove half a litre at a sitting, and this may be repeated at weekly intervals until the blood count is around normal, when the intervals between venesection may be increased. Venerection improves all patients with heart failure except those secondary to anaemia, but it is rarely necessary, failure usually responding quickly to rest, digitalis, mercurial diuretics, and a low sodium diet. When failure is extreme, however, and when it does not seem to be responding satisfactorily to the methods mentioned, venesection can be very helpful. By lowering the venous pressure it unloads the failing heart, and so improves the circulation. It should not, as a rule, be repeated. The usual amount taken off is about half a litre. Venesection may also be used in acute pulmonary oedema which does not respond to posture, venous ligatures on the thighs, morphine, aminophylline, and oxygen.

\section{Therapeutic Abortion in Acute Heart Failure}

Q. -What is the best way of inducing a therapentic abortion in a patient with acute heart failure?

A.-This problem should not arise, because abortion should not be induced in the presence of acute heart failure. Treatment should be directed to the heart condition, and only when compensation is restored is it justifiable to consider terminating the pregnancy. The method then to be adopted depends on the circumstances of the particular case, and these include the duration of the pregnancy, the parity of the patient, and the state of the cervix. If the pregnancy is advanced more than 12 weeks abdominal hysterotomy under local analgesia is often the method of choice.

\section{NOTES AND COMMENTS}

Quaternary Ammonium Antiseptics.-Dr. H. B. MAY (London) writes: The author of the answer to the query ("Any Questions?" May 3, p. 985) does less than justice to some of the large number of quaternary ammonium compounds. The efficiency of some of these substances--e.g., benzalkonium chloride against $P$ s. pyocyanea both in test-tube experiments and on infected skin is equal to that of many widely used antiseptics of the chlor-xylenol type. It is well-known that cetrimide of commercial purity has very little action on Ps. pyocyanea, but it must not be implied that all quaternary ammonium compounds have a similar disadvantage. In an experiment designed to test the relative efficiency of a number of disinfectants on human skin an area of the forearm was heavily contaminated with Ps. pyocyanea and different areas were wiped with solutions of benzalkonium chloride $(0.1 \mathrm{w} / \mathrm{v})$ and a corresponding bromide $(0.1 \% \mathrm{w} / \mathrm{v})$. On subsequent subculture at the end of one minute, both areas of skin showed no growth, while a control area wiped with saline gave a confluent growth of the contaminating organism.

Redheads.-Dr. G. Fielding (Leicester) writes: It is news to me that Jews belong to the dark races ("Any Questions?" May 24 , p. 1143), as their two main types in Europe belong either to the Eastern European group (Ashkenazi) or the Spanish-Dutch group (Sephardi), neither of whom can be called dark. The Sephardi are often very fair, as also are Jews born in Israel. Red-haired Jews are very common.

Correction.-We must apologize to Dr. J. H. Kellgren for an error in his qualifications at the head of his Goulstonian Lectures which were published in our issues of May 24 (p. 1093) and May 31 (p. 1152). Dr. Kellgren is, of course, a Fellow of the Royal College of Physicians of London, not a Member as was stated.

All communications with regard to editorial business should be addressed to The EDITOR, British Medical Journal, B.M.A. House, TAvistoci SOUARE, LONDON, W.C.1 TELEPHONE: EUSTON 4499. TRLBORAMS : Aitiology, Westcent, London. ORIGINAL ARTICL ES AND LETTERS forwarded for publication are understood to be offered to the Britlsh Medical Journal alone unless the contrary be stated

Authors desiring REPRINTS should communicate with the Publishin Manager, B.M.A. House, Tavistock Square, W.C.1, on recetpt of proofi. Authors overseas should indicate on MSS, if reprints are required, as proofs are not sent abroad. ADVERTISEMENTS should be addressed to the Advertisement Manager B.M.A. House, Tavistock Square, London IV.C.1 (hours 9 a.m. to 5 D.m.). TELEPH

MEMBERS SUBSCRIPTIONS should be sent to the SECRETARY of the Association. Telephone: BUSTON 4499. ThlearnMs: Medisecta. Westcent, London.

B.M.A. Scotrish OfFICE: 7, Drumsheugh Gardens, Edinburgh. 